\title{
Detection of Aliphatic Carboxylic Acids Using Tin Oxide Based Gas Sensors
}

\author{
Jun TAMAKI, * Tomonori HAYASHI, Yoshifumi YAMAMOTO, and Masao MATSUOKA
}

\author{
Department of Applied Chemistry, Faculty of Science and Engineering, Ritsumeikan University (1-1-1 Noji-higashi, \\ Kusatsu-shi, Shiga 525-8577, Japan)
}

Received November 18, 2002 ; Accepted February 27, 2003

\begin{abstract}
$\mathrm{SnO}_{2}$ based gas sensors have been investigated for the detection of aliphatic carboxylic acids $\left(\mathrm{C}_{2} \sim \mathrm{C}_{8}\right)$. Among $\mathrm{SnO} 2$ sensors modified with foreign metal oxide, $\mathrm{MoO}_{3^{-}}$, and $\mathrm{WO}_{3}-\mathrm{SnO}_{2}$ sensors showed high sensitivities to aliphatic carboxylic acids, although both sensors exhibited different properties from each other. Catalytic properties of $\mathrm{SnO}_{2}$ based sensor materials have been also evaluated in the oxidation of carboxylic acid in order to be associated with sensing properties. Compared with pure $\mathrm{SnO}_{2}$, the catalytic activity was decreased and the partial oxidation was favored for $\mathrm{WO}_{3}-\mathrm{SnO}_{2}$. For $\mathrm{MoO}_{3}-\mathrm{SnO}_{2}$, the partial oxidation was promoted with the similar activity to pure $\mathrm{SnO}_{2}$, and the cyclic compound like maleic anhydride was produced in the oxidation of carboxylic acid with carbon number larger than 5. These results mean that the consumption of adsorbed oxygen on the surface of sensor material is decreased due to the addition of $\mathrm{WO}_{3}$ and $\mathrm{MoO}_{3}$. It was found that the catalytic activity was too high and most of carboxylic acid were oxidized at sensor surface for pure $\mathrm{SnO}_{2}$ sensor. On the other hand, for $\mathrm{WO}_{3}-$ and $\mathrm{MoO}_{3}-\mathrm{SnO}_{2}$ sensors, the catalytic activity was decreased and the partial oxidation was preferred. This causes the consumption of adsorbed oxygen inside the sensor, inducing the enhancement of sensitivity.
\end{abstract}

Key Words : SnO. Gas Sensor, Carboxylic Acid, Catalytic Oxidation, Surface Modification

\section{Introduction}

These days, there are increasing interests in a detection or discernment of odorous compounds in relation to the application to food, cosmetics, and medical industries as well as amenity or aromatherapy. For this purpose, semiconductor gas sensors such as $\mathrm{SnO}_{2}$ sensors, which can detect combustible gas from their resistance change, seem to be one of the most suitable sensors because of their high sensitivity and stability. Fukui demonstrated the performance of $\mathrm{CaO}-\mathrm{SnO}_{2}$ sensor in his study on the detection of various odorous compounds, and summarized the sensing properties in relation to the functional group of organic compounds. "' Recently, "electronic nose' using a sensor array consisting of plural gas sensors has been actively investigated. ${ }^{2}$ However, the signal processing was mainly studied in the electronic nose. It seems that the performance of electronic nose increases when the sensor designed for each kind of odor is employed for a sensor array. In semiconductor gas sensors, the surface modification can improve the sensing properties of semiconductor gas sensors. ${ }^{3-5}$ ) Namely, the modification by addition of foreign oxide or precious metal makes sensors possible to have high sensitivity as well as high selectivity to particular gas. Previously, $\mathrm{SnO}_{2}$ based sensors were investigated for the detection of various odorous compounds such as alcohols, ${ }^{6}$ ketones, ${ }^{7}$ esters, ${ }^{8}$ and terpenes. ${ }^{9}$ The suitable foreign oxide was found for the detection of each odorous compound in these studies.

In the present paper, we focused aliphatic carboxylic acids $\left(\mathrm{C}_{2}-\mathrm{C}_{8}\right)$ as objective gases for a series of odor sensor investigation. The sensing properties of $\mathrm{SnO}_{2}$-based sensors modified with foreign oxide were systematically examined to detect vapor of aliphatic carboxylic acids. Further, the catalytic properties of $\mathrm{SnO}_{2}$-based sensor materials were evaluated because the oxidation of organic molecules was deeply associated with sensing property. It is known that acetic acid $\left(\mathrm{CH}_{3} \mathrm{COOH}\right)$ and propionic acid $\left(\mathrm{C}_{2} \mathrm{H}_{5} \mathrm{COOH}\right)$ have sharp smell, butyric acid $\left(\mathrm{C}_{3} \mathrm{H}_{7} \mathrm{COOH}\right)$, valeric acid $\left(\mathrm{C}_{4} \mathrm{H}_{9} \mathrm{COOH}\right)$, and hexanoic acid $\left(\mathrm{C}_{5} \mathrm{H}_{11} \mathrm{COOH}\right)$ have offensive smell like excrement, and octanoic acid $\left(\mathrm{C}_{7} \mathrm{H}_{15} \mathrm{COOH}\right)$ has butter-like smell. It is considered that the carboxylic acid sensor in the present paper is useful for bad-smelling gas detection, food-processing, and so on.

\section{Experimental}

The powder of $\mathrm{SnO}_{2}$ was prepared from $\mathrm{SnCl}_{4}$ in wet process. The precipitate (stannic acid) obtained by the neutralization of aqueous $\mathrm{SnCl}_{4}$ solution with aqueous $\mathrm{NH}_{3}$ was calcined at $650^{\circ} \mathrm{C}$ for $4 \mathrm{~h}$ in air. In order to modify $\mathrm{SnO}_{2}$ with foreign oxide, the $\mathrm{SnO}_{2}$ powder was impregnated with metal salt (typically acetate) and calcined at $650^{\circ} \mathrm{C}$ for $4 \mathrm{~h}$ in air. 17 kinds of metal oxides were used here and the loading of them was fixed at 5 wt $\%$. The conventional sintered block-type sensor element, as shown in Fig. 1, was fabricated by using pure and modified $\mathrm{SnO}_{2}$ powder, and sintered at $700^{\circ} \mathrm{C}$ for $4 \mathrm{~h}$ in air. The crystal structure of modified $\mathrm{SnO}_{2}$ powder was examined by means of XRD (Rigaku, RINT2200, 


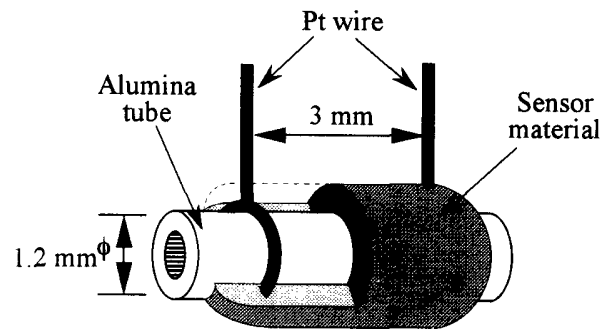

Fig. 1 Schematic drawing of sensor element.

$\mathrm{CuK} \alpha$ radiation). However, any diffraction peaks assigned to foreign oxide were not observed because of small loading. Thus, the state of metal oxide was presumed from calcination temperature as shown in Fig. 2.

For the measurement of sensing properties, the sensor element was set into the flow apparatus. The electrical resistance of sensor element was measured in wet air and in odor containing wet air at $300-500^{\circ} \mathrm{C}$. The sensitivity $(\mathrm{S}=\mathrm{Ra} / \mathrm{Rg})$ was defined as the ratio of resistance in air ( $\mathrm{Ra})$ to that in odor $(\mathrm{Rg})$. The wet air was prepared as follows. The dry air was babbled in deionized water at room temperature to obtain wet air with $100 \%$ relative humidity (RH). The wet air $(\mathrm{RH}=100 \%)$ with $20 \mathrm{~cm}^{3}$ / min of flow rate was mixed with dry air $\left(80 \mathrm{~cm}^{3} / \mathrm{min}\right)$ to obtain wet air $(\mathrm{RH}=20 \%)$ with $100 \mathrm{~cm}^{3} / \mathrm{min}$. On the other hand, the odor containing air was prepared by using the diffusion tube. ${ }^{10 !}$ The diffusion tube containing carboxylic acid was set into thermostat (Gastec PD-10), and the constant amount of carboxylic acid vapor was obtained by flowing dry air into thermostat where the diffusion tube was set. The concentration of carboxylic acid was adjusted to $10 \mathrm{ppm}$ by controlling the flow rate of dry air and thermostat temperature, and by choosing size of diffusion tube. Then the carboxylic acid containing air was mixed with wet air to attain wet condition $(\mathrm{RH}=$ $20 \%)$. The wet condition $(\mathrm{RH}=20 \%)$ was chosen as normal humidity level in the atmosphere because odor sensors in this paper are supposed to be generally used in the atmosphere.

The oxidation of aliphatic carboxylic acids on $\mathrm{SnO}_{2-}$ based sensor materials was carried out by using a fixedbed flow reactor at $150-500^{\circ} \mathrm{C}$. The odor containing air $(\mathrm{RH}=20 \%)$ was flown into the reactor in which $1 \mathrm{~g}$ of $\mathrm{SnO}_{2}$ based powder was set. The effluent was analyzed by gas chromatograph-mass spectrometer (Shimadzu GCMS QP-5050A).

\section{Results and Discussion}

3. 1 Sensing properties to aliphatic carboxylic acids

Figure 2 shows the sensitivities to $10 \mathrm{ppm}$ acetic acid $\left(\mathrm{CH}_{3} \mathrm{COOH}\right)$ of pure $\mathrm{SnO}_{2}$ and 17 kinds of modified $\mathrm{SnO}_{2}$ sensors at $300-500^{\circ} \mathrm{C}$. For all sensors except for $\mathrm{WO}_{3^{-}}$ $\mathrm{SnO}_{2}$ sensor, the sensitivity decreased with increasing operating temperature from 300 to $500^{\circ} \mathrm{C}$. The modification with metal oxide changed the sensitivity of $\mathrm{SnO}_{2}$ sensor in different way. The addition of oxides of $\mathrm{Sr}, \mathrm{Ba}$, $\mathrm{Nd}$, and $\mathrm{Zn}$ enhanced the sensitivity of $\mathrm{SnO}_{2}$ sensor at $300^{\circ} \mathrm{C}$, while the $\mathrm{Rb}_{2} \mathrm{O}-, \mathrm{ZnO}$-, and $\mathrm{MoO}_{3}-\mathrm{SnO}_{2}$ sensors showed the higher sensitivity than pure $\mathrm{SnO}_{2}$ sensor at $400^{\circ} \mathrm{C}$. However, the addition of $\mathrm{MnO}_{2}, \mathrm{Co}_{3} \mathrm{O}_{4}$, and $\mathrm{CuO}$ almost lost the sensitivity to acetic acid of $\mathrm{SnO}_{2}$ sensor at all temperatures examined. The results of hexanoic acid $\left(\mathrm{C}_{5} \mathrm{H}_{11} \mathrm{COOH}\right)$ detection are shown in Fig. 3. The behavior was similar to that for acetic acid, however, the sensitivity of $\mathrm{WO}_{3}-\mathrm{SnO}_{2}$ sensor decreased with increasing operating temperature. The behavior for other carboxylic acids was very similar to that to hexanoic acid. The typical response transients are shown in Fig. 4 for $\mathrm{MoO}_{3}$ $\mathrm{SnO}_{2}$ sensor to $10 \mathrm{ppm}$ acetic acid. At $300^{\circ} \mathrm{C}$, the output voltage sluggishly increased upon exposure to acetic acid and reached steady state after $15 \mathrm{~min}$. On the other hand,

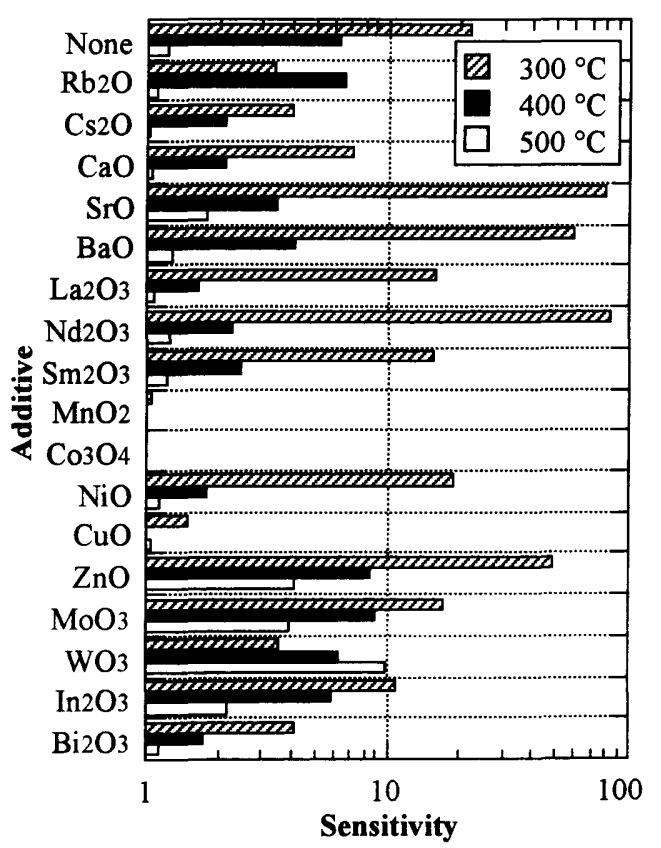

Fig. 2 Sensitivities to 10 ppm acetic acid of $\mathrm{SnO}_{2}$ based sensors modified with various additives at $300-500{ }^{\circ} \mathrm{C}$.

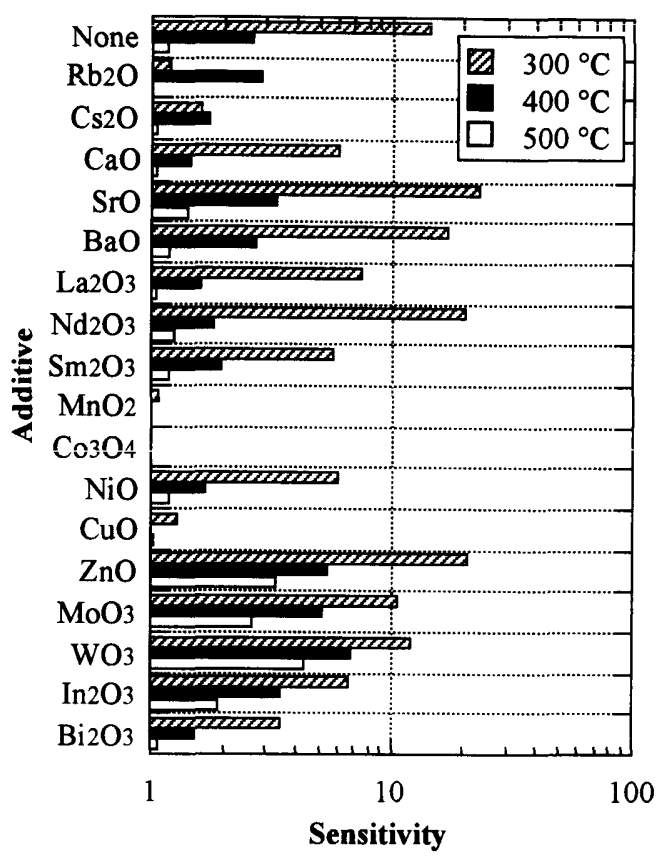

Fig. 3 Sensitivities to $10 \mathrm{ppm}$ hexanoic acid of $\mathrm{SnO}_{2}$ based sensors modified with various additives at $300-500^{\circ} \mathrm{C}$. 


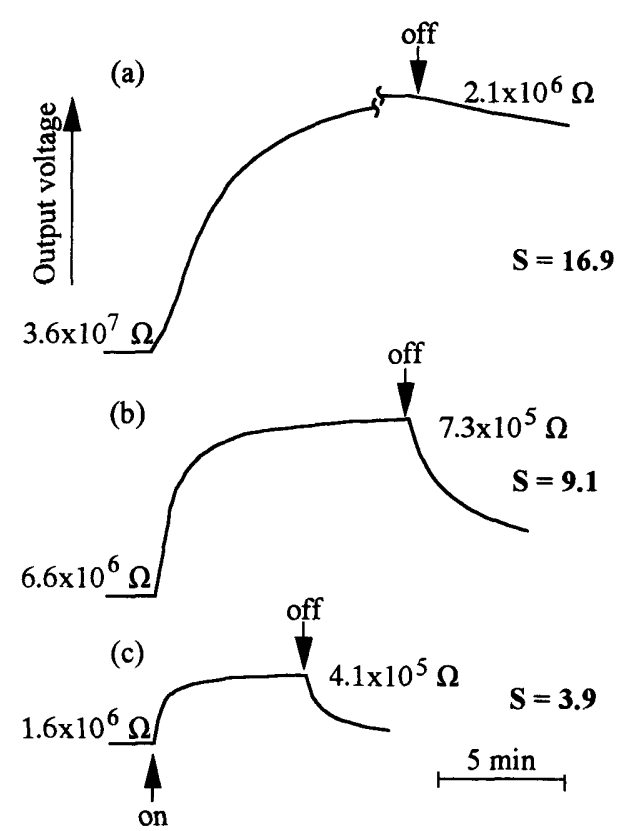

Fig. 4 Response transients of $\mathrm{MoO}_{3}-\mathrm{SnO}_{2}$ sensor to $10 \mathrm{ppm}$ acetic acid at (a) $300^{\circ} \mathrm{C}$, (b) $400^{\circ} \mathrm{C}$, and (c) $500^{\circ} \mathrm{C}$.

the rates of response and recovery were increased at $400^{\circ} \mathrm{C}$. The resistance decreased to steady state within 3 min upon exposure to acetic acid, and recovered to initial level within $15 \mathrm{~min}$ when air flow was resumed. At $500^{\circ} \mathrm{C}$, the response-recovery characteristics were further improved. However, the sensitivity decreased with increasing operating temperarture. Thus, the optimal operating temperature was $400^{\circ} \mathrm{C}$ from the trade-off of sensitivity and response-recovery characteristics. At optimal temperature of $400^{\circ} \mathrm{C}$, it was found that $\mathrm{ZnO}, \mathrm{MoO}_{3}$, and $\mathrm{WO}_{3}$ were effective in enhancing the sensitivity of $\mathrm{SnO}_{2}$ sensor to carboxylic acids.

The sensitivities to carboxylic acids of $\mathrm{SnO}_{2}$ based sensors were correlated with carbon number of carboxylic acid at $400^{\circ} \mathrm{C}$. As a result, two types of correlations were obtained. In one type, the sensitivities almost monotonously decreased with increasing carbon mumber. Pure,

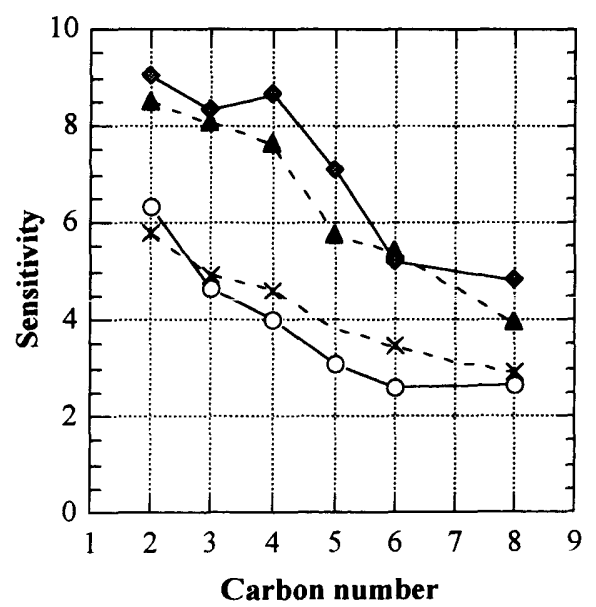

Fig. 5 Sensitivities to various carboxylic acids of $\mathrm{SnO}_{2}$ based sensors as a function of carbon number in carboxylic acid.

- - - : Pure $\mathrm{SnO}_{2}, \boldsymbol{- - A - -}: \mathrm{ZnO}_{-} \mathrm{SnO}_{2}, \longrightarrow$ $\mathrm{MoO}_{3}-\mathrm{SnO}_{2}, \mathbf{-}-\boldsymbol{X} \boldsymbol{-}-\boldsymbol{:}: \mathrm{In}_{2} \mathrm{O}_{3}-\mathrm{SnO}_{2}$.

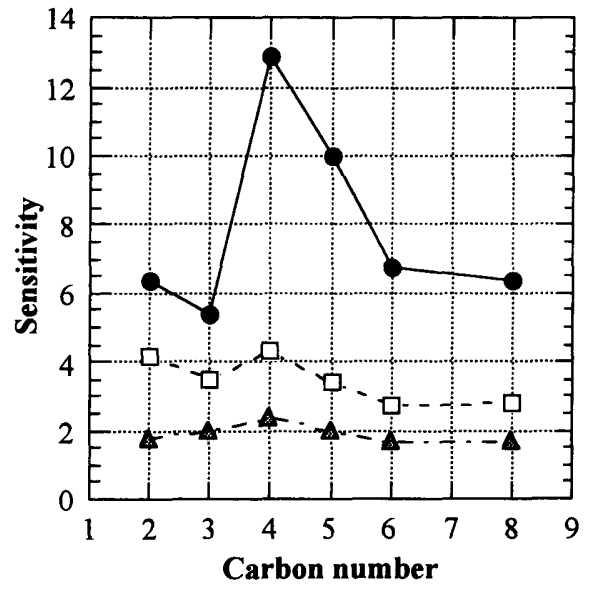

Fig. 6 Sensitivities to various carboxylic acid of $\mathrm{SnO}_{2}$ based sensors as a function of carbon number in carboxylic acid. - - - - - : $\mathrm{BaO}_{-} \mathrm{SnO}_{2},-\mathbf{A}^{--}: \mathrm{NiO}-\mathrm{SnO}_{2}, \longrightarrow$ $\mathrm{SnO}_{2}$.

$\mathrm{ZnO}-, \mathrm{MoO}_{3}$, and $\mathrm{In}_{2} \mathrm{O}_{3}-\mathrm{SnO}_{2}$ sensors belonged this type among the sensors showed good sensitivity. As shown in Fig. $5, \mathrm{MoO}_{3-}$ and $\mathrm{ZnO}-\mathrm{SnO}_{2}$ sensors showed high sensitivities to all of carboxylic acids, especially to $\mathrm{C}_{2}-\mathrm{C}_{4}$ acids, suggesting these sensors to be good carboxylic acid sensor. In another type, the sensitivity had a maximum at butyric acid in the sensitivity-carbon number correlation. The $\mathrm{WO}_{3}, \mathrm{BaO}-, \mathrm{NiO}-\mathrm{SnO}_{2}$ sensors were included in this type as shown in Fig. 6. The $\mathrm{WO}_{3}-\mathrm{SnO}_{2}$ sensor exhibited the highest sensitivity $(\mathrm{S}=12.9)$ to butyric acid, suggesting the $\mathrm{WO}_{3}-\mathrm{SnO}_{2}$ sensor to be butyric acid selective sensor.

3. 2 Catalytic oxidation of aliphatic carboxylic acid on $\mathrm{SnO}_{2}$ based catalysts

A semiconductor gas sensor can detect combustible gas from a resistance change due to consumption of adsorbed oxygen in the oxidation of gas on the surface of sensor material. It is considered that most of additives influences the catalytic properties of $\mathrm{SnO}_{2}$ in the oxidation of combustible gas and thus changes the sensitivity. In order to elucidate why particular additive was effective in the detection of carboxylic acid using $\mathrm{SnO}_{2}$ sensor, the catalytic oxidation of carboxylic acids was examined for $\mathrm{SnO}_{2}$ based catalysts. The catalytic properties were investigated for $\mathrm{SnO}_{2}$ powders modified with $\mathrm{WO}_{3}$ and $\mathrm{MoO}_{3}$ which showed the highest sensitivity in each type of sensitivity-carbon number correlation. The catalytic properties of pure $\mathrm{SnO}_{2}$ was also examined for comparison.

Figure 7 shows conversions in the oxidation of carboxylic acid on pure $\mathrm{SnO}_{2}$ catalyst as typical example. The conversion began to increase at $150-250^{\circ} \mathrm{C}$ and reached almost $100 \%$ at $300-350^{\circ} \mathrm{C}$. The temperature at which the conversion began to increase depended on kind of carboxylic acid. This temperature was the lowest for butyric acid oxidation, and was the highest for acetic acid oxidation. The catalytic activity was evaluated by using $\mathrm{T}_{50 \%}$ parameter. $\mathrm{T}_{50 \%}$ was defined as a temperature at which the conversion reached $50 \%$. The increase in $\mathrm{T}_{50 \%}$ value means the decrease in catalytic activity. Figure $8 \mathrm{de}$ picted $T_{50 \%}$ values in the oxidation of carboxylic acid on 


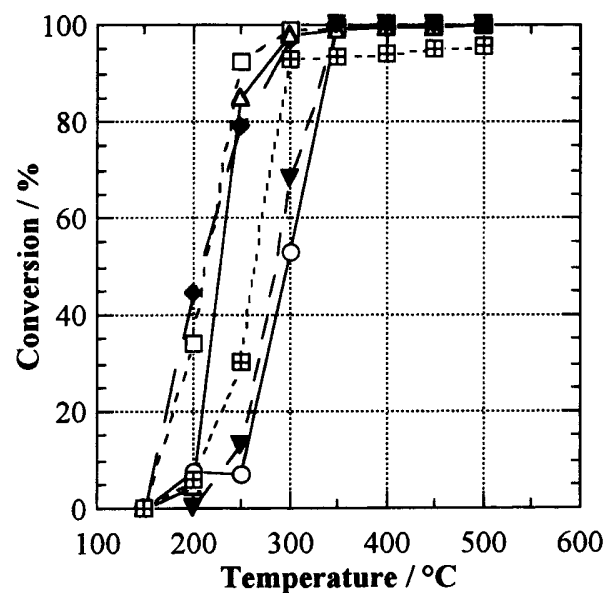

Fig. 7 Conversions of carboxylic acid in the catalyic oxidation on pure $\mathrm{SnO}_{2}$ as a function of reaction temperature. $\longrightarrow$ - $:$ : Acetic acid, - - $\mathbf{0 - -}:$ Propionic acid, $\longrightarrow-$ : Butyric acid, $\longrightarrow$ - Valeric acid, -- $\mathbf{-}-\mathbf{- -}$ : Hexanoic acid, $\mathbf{Z}$ - : Octanoic acid.

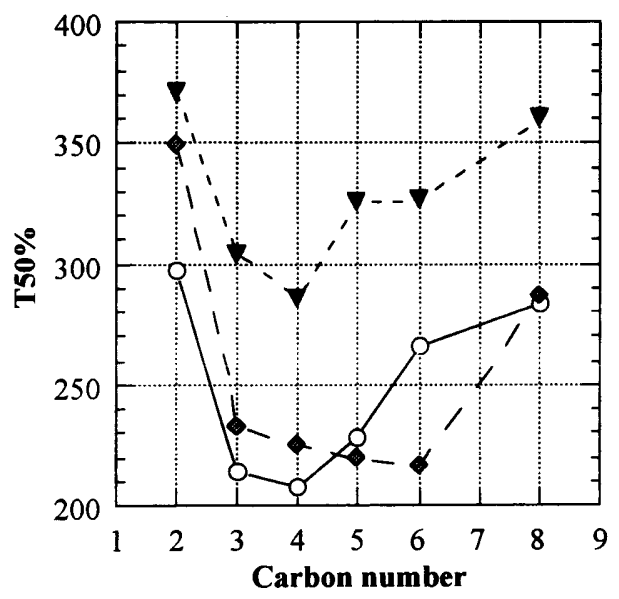

Fig. 8 Catalytic activities of $\mathrm{SnO}_{2}$ based catalysts in the oxidation of carboxylic acid as a function of carbon number. $\longrightarrow$ - : Pure $\mathrm{SnO}_{2}, \boldsymbol{-}-$ : $\mathrm{WO}_{3}-\mathrm{SnO}_{2}, \longrightarrow$ $\mathrm{MoO}_{3}-\mathrm{SnO}_{2}$. pure, $\mathrm{WO}_{3^{-}}$, and $\mathrm{MoO}_{3}-\mathrm{SnO}_{2}$ catalysts as a function of carbon number of carboxylic acid. For pure $\mathrm{SnO}_{2}$ catalyst, $\mathrm{T}_{50 \%}$ value was $300^{\circ} \mathrm{C}$ for acetic acid $\left(\mathrm{C}_{2}\right)$ and became minimum for butyric acid $\left(\mathrm{C}_{4}\right)$. $\mathrm{T}_{50 \%}$ changed in the range of $200-300^{\circ} \mathrm{C}$. For $\mathrm{WO}_{3}-\mathrm{SnO}_{2}$ catalyst, $\mathrm{T}_{50 \%}$ shifted to higher temperature side compared with those for pure $\mathrm{SnO}_{2}$, although $\mathrm{T}_{50 \%}$ also had minimum for butyric acid. Namely, $\mathrm{T}_{50 \%}$ changed in the range of $280-370^{\circ} \mathrm{C}$ for $\mathrm{WO}_{3}$ $\mathrm{SnO}_{2}$. Further, $\mathrm{T}_{50 \%}$ was $370^{\circ} \mathrm{C}$ in the oxidation of acetic acid, suggesting the low catalytic activity of $\mathrm{WO}_{3}-\mathrm{SnO}_{2}$. It is considered that acetic acid is hardly oxidized on $\mathrm{WO}_{3}-$ $\mathrm{SnO}_{2}$ at $300^{\circ} \mathrm{C}$, inducing the low sensitivity at this temperature as shown in Fig. 2. On the other hand, $\mathrm{T}_{50 \%}$ for $\mathrm{MoO}_{3}-\mathrm{SnO}_{2}$ varied in the similar range to pure $\mathrm{SnO}_{2}$. These results suggest that butyric acid is easily oxidized irrespective of catalyst and that the addition of $\mathrm{WO}_{3}$ decreased the catalytic activity and $\mathrm{MoO}_{3}-\mathrm{SnO}_{2}$ had similar activity to pure $\mathrm{SnO}_{2}$.

In order to elucidate the reaction pass, the intermediates produced at low temperature before completely oxidized to $\mathrm{CO}_{2}$ and $\mathrm{H}_{2} \mathrm{O}$ were investigated in detail. The intermediates produced in the oxidation of carboxylic acid on $\mathrm{SnO}_{2}$ based catalysts are summarized in Table 1. Depending on the intermediates produced, the reactants were classified into 3 groups. In the oxidation of acetic acid $\left(C_{2}\right)$, which belonged the first group, only formaldehyde $\left(C_{1}\right)$ was formed on all catalysts. However, the intermediates were more complicated with increasing carbon number of carboxylic acid. In group II which includes $\mathrm{C}_{3}$ and $\mathrm{C}_{4}$ carboxylic acids, aldehydes and alkenes were produced in the oxidation of carboxylic acid. On the other hand, from the group III $\left(\mathrm{C}_{5} \sim \mathrm{C}_{8}\right.$ carboxylic acids), the cyclic compounds like furan and meleic anhydride were observed in addition to aldehydes and alkenes. Further, in the oxidation of groups II and III carboxylic acids, alkenes were not observed on pure $\mathrm{SnO}_{2}$ catalyst, and acetic acid was conspicuously observed on

Table 1 Intermediates produced in the oxidation of carboxylic acid on $\mathrm{SnO}_{2}$ based catalysts.

\begin{tabular}{|c|c|c|c|c|}
\hline \multirow[t]{2}{*}{ Group } & \multirow[t]{2}{*}{ Reactant } & \multicolumn{3}{|c|}{ Catalyst } \\
\hline & & Pure $\mathrm{SnO}_{2}$ & $\mathrm{WO}_{3}-\mathrm{SnO}_{2}$ & $\mathrm{MoO}_{3}-\mathrm{SnO}_{2}$ \\
\hline I & $\mathrm{CH}_{3} \mathrm{COOH} \quad\left(\mathrm{C}_{2}\right)$ & $\mathrm{HCHO}\left(\mathrm{C}_{1}\right)$ & $\mathrm{HCHO}\left(\mathrm{C}_{1}\right)$ & $\mathrm{HCHO}\left(\mathrm{C}_{1}\right)$ \\
\hline \multirow[t]{2}{*}{ II } & $\mathrm{C}_{2} \mathrm{H}_{5} \mathrm{COOH} \quad\left(\mathrm{C}_{3}\right)$ & $\mathrm{C}_{1} \sim \mathrm{C}_{2}$ aldehydes & $\begin{array}{l}\mathrm{CH}_{2}=\mathrm{CH}_{2}\left(\mathrm{C}_{2}\right) \\
\mathrm{C}_{1} \sim \mathrm{C}_{2} \text { aldehydes }\end{array}$ & $\begin{array}{l}\mathrm{CH}_{2}=\mathrm{CH}_{2}\left(\mathrm{C}_{2}\right) \\
\mathrm{CH}_{3} \mathrm{COOH} \\
\mathrm{C}_{1} \sim \mathrm{C}_{2} \text { aldehydes }\end{array}$ \\
\hline & $\mathrm{C}_{3} \mathrm{H}_{7} \mathrm{COOH} \quad\left(\mathrm{C}_{4}\right)$ & $\mathrm{C}_{1} \sim \mathrm{C}_{3}$ aldehydes & $\begin{array}{l}\mathrm{C}_{2}, \mathrm{C}_{3} \text { alkenes } \\
\mathrm{C}_{1} \sim \mathrm{C}_{3} \text { aldehydes }\end{array}$ & $\begin{array}{l}\mathrm{C}_{2}, \mathrm{C}_{3} \text { alkenes } \\
\mathrm{CH}_{3} \mathrm{COOH} \\
\mathrm{C}_{2} \text { aldehydes }\end{array}$ \\
\hline \multirow[t]{3}{*}{ III } & $\mathrm{C}_{4} \mathrm{H}_{9} \mathrm{COOH} \quad\left(\mathrm{C}_{5}\right)$ & $\begin{array}{l}\mathrm{C}_{1} \sim \mathrm{C}_{4} \text { aldehydes } \\
\text { Furan }\end{array}$ & $\begin{array}{l}\mathrm{C}_{3}, \mathrm{C}_{4} \text { alkenes } \\
\mathrm{C}_{1} \sim \mathrm{C}_{4} \text { aldehydes } \\
\text { Furan } \\
\text { Maleic anhydride }\end{array}$ & $\begin{array}{l}\mathrm{CH}_{3} \mathrm{COOH} \\
\mathrm{C}_{1} \sim \mathrm{C}_{4} \text { aldehydes } \\
\mathrm{C}_{3}, \mathrm{C}_{4} \text { alkenes } \\
\text { Furan } \\
\text { Maleic anhydride }\end{array}$ \\
\hline & $\mathrm{C}_{5} \mathrm{H}_{11} \mathrm{COOH}\left(\mathrm{C}_{6}\right)$ & $\begin{array}{l}\mathrm{C}_{1} \sim \mathrm{C}_{5} \text { aldehydes } \\
\text { Furan }\end{array}$ & $\begin{array}{l}\mathrm{C}_{4}, \mathrm{C}_{5} \text { alkenes } \\
\mathrm{C}_{1} \sim \mathrm{C}_{5} \text { aldehydes } \\
\text { Maleic anhydride }\end{array}$ & $\begin{array}{l}\mathrm{CH}_{3} \mathrm{COOH} \\
\mathrm{C}_{4}, \mathrm{C}_{5} \text { alkenes } \\
\mathrm{C}_{1} \sim \mathrm{C}_{5} \text { aldehydes } \\
\text { Maleic anhydride }\end{array}$ \\
\hline & $\mathrm{C}_{7} \mathrm{H}_{15} \mathrm{COOH}(\mathrm{C} 8)$ & $\begin{array}{l}\mathrm{C}_{1} \sim \mathrm{C}_{7} \text { aldehydes } \\
\text { Maleic anhydride }\end{array}$ & $\begin{array}{l}\mathrm{C}_{7} \text { alkene } \\
\mathrm{C}_{1} \sim \mathrm{C}_{7} \text { aldehydes } \\
\text { Maleic anhydride } \\
\mathrm{CH}_{3} \mathrm{COOH}\end{array}$ & $\begin{array}{l}\mathrm{CH}_{3} \mathrm{COOH} \\
\mathrm{C}_{1} \sim \mathrm{C}_{7} \text { aldehydes } \\
\mathrm{C}_{7} \text { alkene } \\
\text { Maleic anhydride }\end{array}$ \\
\hline
\end{tabular}


$\mathrm{MoO}_{3}-\mathrm{SnO}_{2}$ catalyst. From the results of intermediates, the simple rule was easily found for all of reactants and $\mathrm{SnO}_{2}$ based catalysts as follows. In the oxidation of carboxylic acid with carbon number of $n\left(C_{n}\right.$ carboxylic acid), $C_{1} \sim C_{n-1}$ aldehydes, $C_{n-2}$ and $C_{n-1}$ alkenes $(n \geqq 2)$, and $\mathrm{C}_{4}$ cyclic compounds such as furan and maleic anhydride ( $\mathrm{n} \geqq 5$ ) were formed as intermediates.

The results in the oxidation of propionic acid $\left(\mathrm{C}_{3}\right)$ on $\mathrm{SnO}_{2}$ based catalysts are shown in Fig. 9 as typical example of group II carboxylic acid. The normal axis means the amount of gas included in $1 \mathrm{~cm}^{3}$ of effluent. On pure $\mathrm{SnO}_{2}$ catalyst, acetaldehyde was produced at $200-350^{\circ} \mathrm{C}$
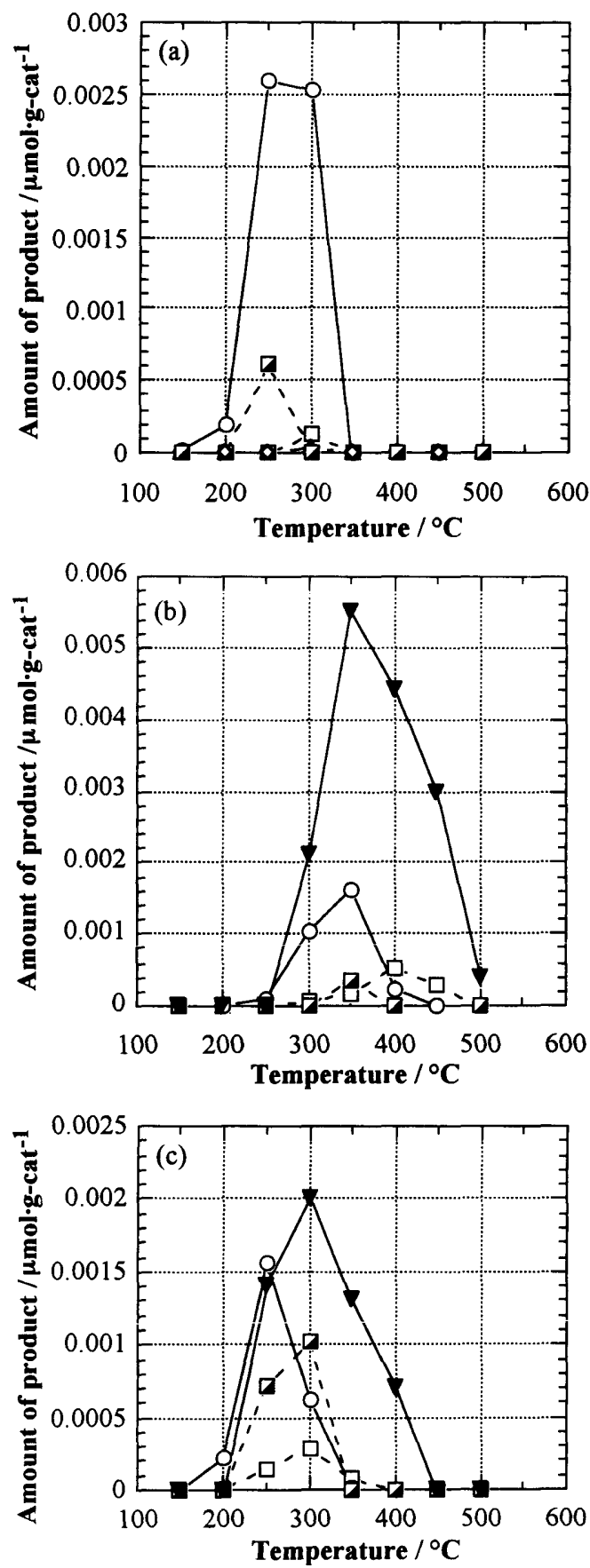

Fig. 9 Amount of product in the oxidation of propionic acid on $\mathrm{SnO}_{2}$ based catalysts as a function of reaction temperature. (a) Pure $\mathrm{SnO}_{2}$, (b) $\mathrm{WO}_{3}-\mathrm{SnO}_{2}$, (c) $\mathrm{MoO}_{3}-\mathrm{SnO}_{2}$.

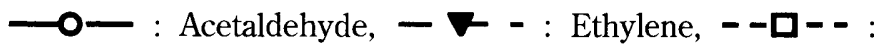
Formaldehyde, $\cdots \nabla \cdots \cdot$ : Acetic acid. as major product, while ethylene and acetaldehyde were dominantly produced on $\mathrm{WO}_{3-}$, and $\mathrm{MoO}_{3}-\mathrm{SnO}_{2}$ catalysts. But, these appeared at higher temperature on $\mathrm{WO}_{3}-\mathrm{SnO}_{2}$ catalyst. Further, acetic acid was largely detected on $\mathrm{MoO}_{3}-\mathrm{SnO}_{2}$ catalyst. As an example of group III carboxylic acid, the results in the oxidation of valeric acid are shown in Figs. 10-12 for pure, $\mathrm{WO}_{3-}$, and $\mathrm{MoO}_{3}-\mathrm{SnO}_{2}$ catalysts, respectively. On pure $\mathrm{SnO}_{2}$, butyraldehyde was major product, and $\mathrm{C}_{1} \sim \mathrm{C}_{3}$ aldehydes and furan $\left(\mathrm{C}_{4}\right)$ were also observed at $200-350^{\circ} \mathrm{C}$. On $\mathrm{WO}_{3}-\mathrm{SnO}_{2}$ catalyst, propene $\left(\mathrm{C}_{3}\right)$ and 1-butene $\left(\mathrm{C}_{4}\right)$, and propionaldehyde $\left(\mathrm{C}_{3}\right)$ and butyraldehyde $\left(\mathrm{C}_{4}\right)$ were dominantly produced at $250-400^{\circ} \mathrm{C}$, while formaldehyde $\left(\mathrm{C}_{1}\right)$ and acetaldehyde $\left(\mathrm{C}_{2}\right)$ were observed at higher temperature. On the other hand, on $\mathrm{MoO}_{3}-\mathrm{SnO}_{2}$ catalyst, formaldehyde $\left(\mathrm{C}_{1}\right)$ and acetaldehyde $\left(\mathrm{C}_{2}\right)$ were produced at $200-400^{\circ} \mathrm{C}$ after small formation of propionaldehyde $\left(\mathrm{C}_{3}\right)$ and butyraldehyde $\left(\mathrm{C}_{4}\right)$, while 1-butene $\left(\mathrm{C}_{4}\right)$ and propene $\left(\mathrm{C}_{3}\right)$, maleic anhydride $\left(\mathrm{C}_{4}\right)$, and acetic acid $\left(\mathrm{C}_{2}\right)$ were also observed as major products. From the behavior of aldehydes formation, $\mathrm{C}_{1}, \mathrm{C}_{2}$ aldehydes are considered to be consecutive products from $\mathrm{C}_{3}, \mathrm{C}_{4}$ aldehydes. Further, it is noteworthy on $\mathrm{MoO}_{3}-\mathrm{SnO}_{2}$ that maleic anhydride still remains at elevated temperature higher than $400^{\circ} \mathrm{C}$ and that acetic acid is largely produced. From the temperature at which intermediates were formed, it was found that the catalytic activity increased in the order of $\mathrm{WO}_{3}-\mathrm{SnO}_{2}<\mathrm{MoO}_{3}-\mathrm{SnO}_{2}$ $\approx$ pure $\mathrm{SnO}_{2}$. This was in good agreement with the result of Fig. 8. Moreover, at optimal operating temperature of $400^{\circ} \mathrm{C}$ for $\mathrm{SnO}_{2}$ based sensors, any intermediates were not observed on pure $\mathrm{SnO}_{2}$, while some of intermediates remained for $\mathrm{WO}_{3^{-}}$and $\mathrm{MoO}_{3}-\mathrm{SnO}_{2}$. This suggests that the complete oxidation of carboxylic acid proceeds on pure $\mathrm{SnO}_{2}$, while the partial oxidation is preferred on $\mathrm{WO}_{3^{-}}$and $\mathrm{MoO}_{3}-\mathrm{SnO}_{2}$. The feature of catalytic properties is summarized as follows.

1) Pure $\mathrm{SnO}_{2}$ has high catalytic activity in the oxidation of carboxylic acid. The complete oxidation proceeds on pure $\mathrm{SnO}_{2}$ at $400^{\circ} \mathrm{C}$.

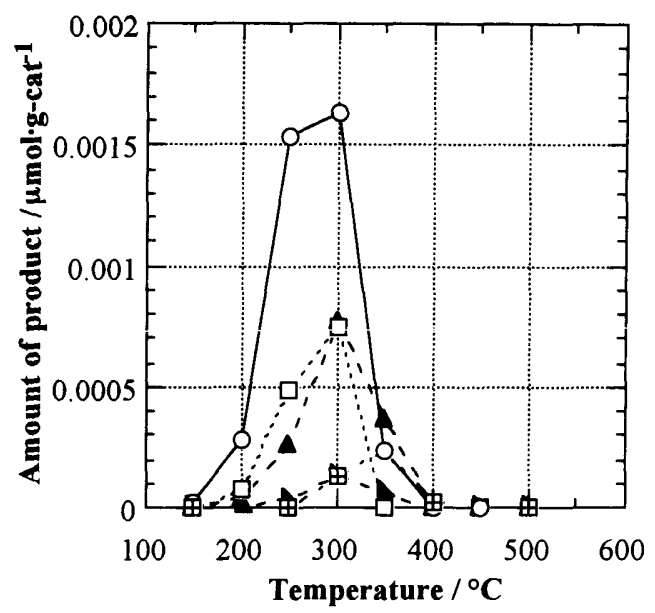

Fig. 10 Amount of product in the oxidation of valeric acid on pure $\mathrm{SnO}_{2}$ catalyst as a function of reaction temperature. - - : Butyraldehyde, - - $\mathbf{- 0}$ : Propionaldehyde, -- $\mathbf{H - -}$ : Furan, - - - - : Acetaldehyde, - - - - : Formaldehyde. 

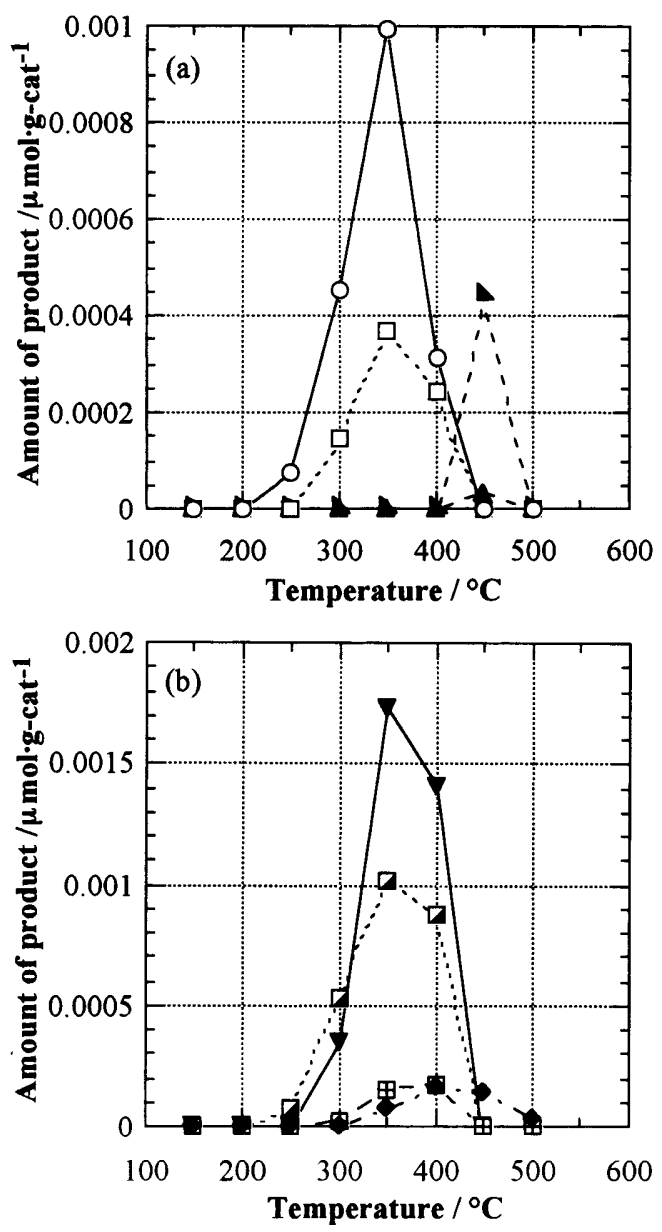

Fig. 11 Amount of product in the oxidation of valeric acid on $\mathrm{WO}_{3-} \mathrm{SnO}_{2}$ catalyst as a function of reaction temperature.

(a) Aldehydes, (b) Alkenes and cyclic compounds.

- - : Butyraldehyde, - - - - - : Propionaldehyde,

- - - - : Acetaldehyde, - - - - : Formaldehyde,

- $\mathbf{-}-$ : 1-Butene, --- $\mathbf{- - -}$ : Propene, -- $\mathbf{- 1 - -}:$ Furan,

: Maleic anhydride.

2) $\mathrm{WO}_{3}-\mathrm{SnO}_{2}$ not only has lower catalytic activity than pure $\mathrm{SnO}_{2}$, but also favors the partial oxidation at $400^{\circ} \mathrm{C}$.

3) $\mathrm{MoO}_{3}-\mathrm{SnO}_{2}$ has similar catalytic activity to pure $\mathrm{SnO}_{2}$, but the partial oxidation is preferred at $400^{\circ} \mathrm{C}$.

The possible reaction pass in the oxidation of $\mathrm{C}_{n}$ carboxylic acid was considered as shown in Fig. 13. It is known that hydroxyl group is added to $\alpha$ or $\beta$ position of carboxyl acid when the acid is oxidized in wet air, and these additions are called as $\alpha$-or $\beta$-hydroxylation When hydroxyl group is added to $\alpha$-position, $\mathrm{CO}_{2}$ is removed from the molecule to form alcohol like intermediate with carbon number of $(n-1)$. On the other hand, $\mathrm{CH}_{3} \mathrm{COOH}$ is removed from the $\beta$-hydroxylized molecule to form alcohol like intermediate with carbon number of $(\mathrm{n}-2)$. Further, alcohol like intermediate is oxidized to produce aldehydes by dehydrogenation or alkenes by dehydration. The surface acid-base property of catalyst determines which reaction of dehydrogenation or dehydration dominantly proceeds in the oxidation of alcohol. ${ }^{11}$ $\mathrm{SnO}_{2}$ is known to be slightly basic oxide and thus the dehydrogenation to form aldehydes is favored on pure
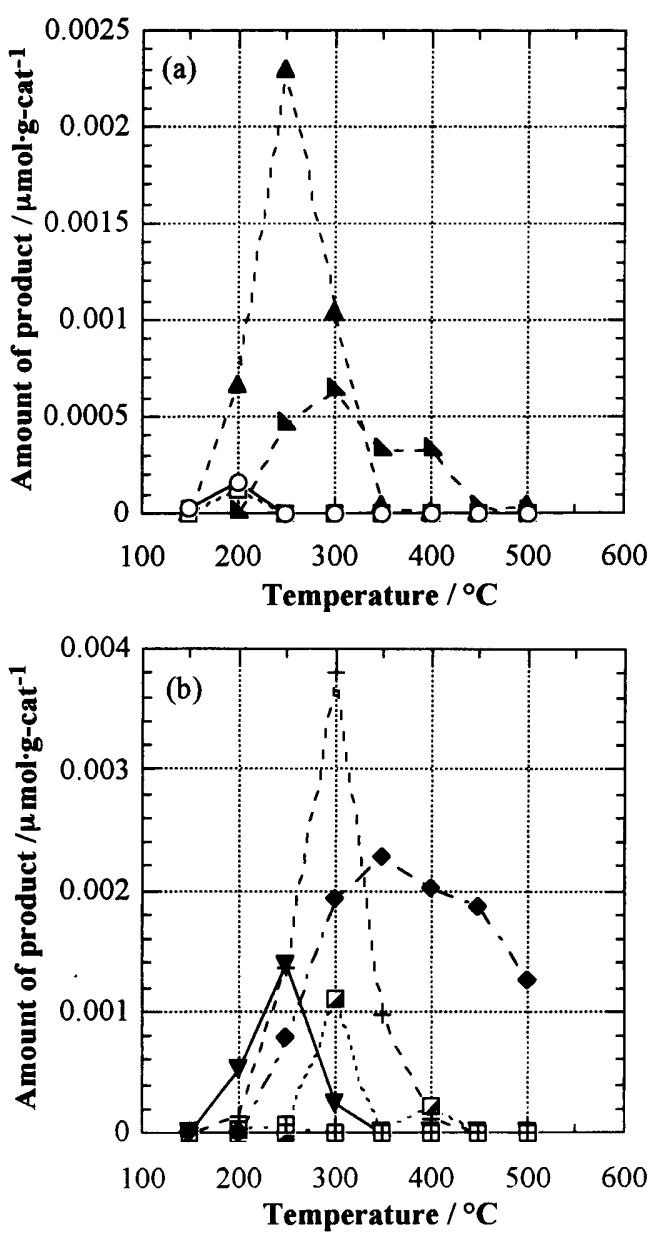

Fig. 12 Amount of product in the oxidation of valeric acid on $\mathrm{MoO}_{3}-\mathrm{SnO}_{2}$ catalyst as a function of reaction temperature.

(a) Aldehydes, (b) Alkenes, cyclic compounds, and others.

- - : Butyraldehyde, - - $\mathbf{0 - -}$ : Propionaldehyde,

- - - - : Acetaldehyde, - - - - : Formaldehyde,

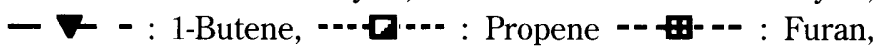

: Maleic anhydride, - -+ - - : Acetic acid.
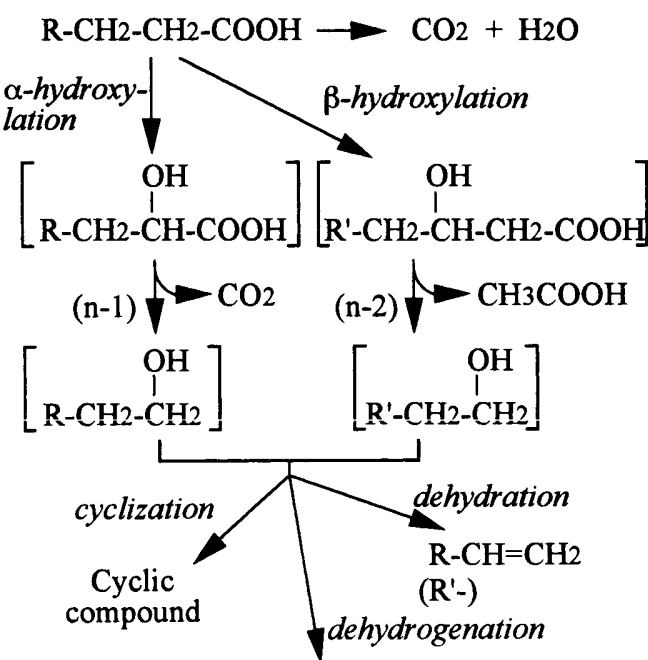

R-CH2-CHO

(R'-)

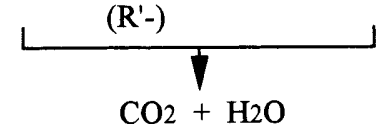

Fig. 13 Reaction route in the oxidation of carboxylic acid on $\mathrm{SnO}_{2}$ based catalyst. 
$\mathrm{SnO}_{2}$. On $\mathrm{WO}_{3}$, and $\mathrm{MoO}_{3}-\mathrm{SnO}_{2}$ catalysts, the surface of $\mathrm{SnO}_{2}$ is modified to acidic because $\mathrm{WO}_{3}$ and $\mathrm{MoO}_{3}$ are acidic oxide. The dehydration to alkene is preferred on $\mathrm{WO}_{3-}$, and $\mathrm{MoO}_{3}-\mathrm{SnO}_{2}$. In the oxidation of acetic acid, only $\alpha$-hydroxylation occurs to form methanol like intermediate. This is consecutively oxidized only to formaldehyde by dehydrogenation. When the carbon number is larger than 5 , it is possible that $\mathrm{C}_{4}$ alcohol like intermediate is dehydrogenated and cyclized to form furan. Furan is consecutively oxidized to form maleic anhydride. At last, these compounds are completely oxidized to $\mathrm{CO}_{2}$ and $\mathrm{H}_{2} \mathrm{O}$. It is considered that aldehydes with smaller carbon number are formed due to the oxidation of $\mathrm{C}_{\mathrm{n}-1}$ or $\mathrm{C}_{\mathrm{n}-2}$ carboxyl acid intermediate produced from $\mathrm{C}_{\mathrm{n}-1}$ or $\mathrm{C}_{\mathrm{n}-2}$ aldehyde intermediate.

3. 3 Relationship between sensing properties and catalytic properties

$\mathrm{Xu}$ et al. investigated the dispersion of foreign oxide and electronic interaction in $\mathrm{SnO}_{2}$-besed powders. ${ }^{12)}$ Among foreign oxides related to the present study, $\mathrm{Co}_{3}$ $\mathrm{O}_{4}$ tended to aggregate to grow large particle on $\mathrm{SnO}_{2}$ surface. On the other hand, most of oxides other than $\mathrm{Co}_{3} \mathrm{O}_{4}$ highly dispersed as fine grains on $\mathrm{SnO}_{2}$ surface and did not affect the electrical properties of $\mathrm{SnO}_{2}$ so much. Thus, it is considered that the foreign oxide influences the morphology as well as the surface properties of $\mathrm{SnO}_{2}$ and that these factors totally affect the catalytic properties. The catalytic properties of $\mathrm{SnO}_{2}, \mathrm{WO}_{3}-\mathrm{SnO}_{2}$, and $\mathrm{MoO}_{3}-\mathrm{SnO}_{2}$ were qualitatively correlated with the sensing properties as described below.

It is noted that the inverse curve for $\mathrm{WO}_{3}-\mathrm{SnO}_{2}$ in Fig. 8 is very similar to sensitivity curve for $\mathrm{WO}_{3}-\mathrm{SnO}_{2}$ in Fig. 6. This suggests that $280^{\circ} \mathrm{C}$ of $T_{50 \%}$ is optimal for high sensitivity and this condition is realized for butyric acid sensing by $\mathrm{WO}_{3}-\mathrm{SnO}_{2}$ sensor. For other carboxylic acids, the $\mathrm{WO}_{3}-\mathrm{SnO}_{2}$ sensor showed low sensitivity because of low catalytic activity. On the other hand, pure $\mathrm{SnO}_{2}$ showed $\mathrm{T}_{50 \%}=295^{\circ} \mathrm{C}$ for acetic acid and catalytic activity increased with increasing carbon number until $\mathrm{C}_{4}$. The sensitivity of pure $\mathrm{SnO}_{2}$ sensor was the highest for acetic acid and decreased with increasing carbon number. Thus, it is seen that the sensitivity is the highest at moderate catalytic activity $\left(T_{50 \%}=280^{\circ} \mathrm{C}\right)$ and that the lower or the higher activity decreases the sensitivity. The resistance is measured at the part between electrodes inside the sensor element as shown in Fig. 1. The resistance change at this part contributes the sensitivity of sensor. When the catalytic activity is too low, the consumption of adsorbed oxygen is small at this part, inducing low sensitivity. With the moderate activity, the adsorbed oxygen is effectively consumed at this part, resulting in high sensitivity. However, when the activity is too high, the combustible gas is oxidized at surface of sensor element and can not diffuse inside the element. In this case, the sensitivity is decreased. The pure $\mathrm{SnO}_{2}$ sensor showed the moderate or low sensitivities to carboxylic acids because of high catalytic activity of pure $\mathrm{SnO}_{2}$, while the addition of $\mathrm{WO}_{3}$ decreased the catalytic activity, enhancing the sensitivity. It is considered that the results in the present study are the first example that the high sensitivity is obtained by decreasing well the catalytic activity.

On the other hand, $\mathrm{MoO}_{3}-\mathrm{SnO}_{2}$ had similar activity to pure $\mathrm{SnO}_{2}$, but the $\mathrm{MoO}_{3}-\mathrm{SnO}_{2}$ sensor showed the higher sensitivity than pure $\mathrm{SnO}_{2}$ sensor. The partial oxidation preferentially occurred on $\mathrm{MoO}_{3}-\mathrm{SnO}_{2}$, suggesting that the consumption of adsorbed oxygen was smaller than pure $\mathrm{SnO}_{2}$ on which complete oxidation was favored. For $\mathrm{MoO}_{3}-\mathrm{SnO}_{2}$ sensor, the products of partial oxidation would diffuse into the part between electrodes and would be oxidized, inducing the enhancement of sensitivity.

Although both $\mathrm{WO}_{3}$ and $\mathrm{MoO}_{3}$ made the $\mathrm{SnO}_{2}$ surface acidic, the catalytic properties were modified in different way because the catalytic activity and intermediates produced were different from each other in $\mathrm{WO}_{3-}$ and $\mathrm{MoO}_{3-}$ $\mathrm{SnO}_{2}$ as aforementioned. These modifications totally affect the consumption of adsorbed oxygen, inducing the difference in sensing properties. Thus, it is considered that the $\mathrm{WO}_{3}-\mathrm{SnO}_{2}$ sensor exhibited the optimal oxygen consumption for butyric acid sensing and thus the sensor showed the maximum sensitivity to butyric acid.

\section{References}

1) K. Fukui, Sensors and Actuators B , 5, 27 (1991).

2) For example, J. W. Gardner and P.N. Bartlett, Sensor and Actuators B, 18-19, 211 (1994).

3) N. Miura, J. Tamaki, and N. Yamazoe, Hyomen, 28, 15 (1990).

4) N. Yamazoe and N. Miura, Chemical Sensor Technology Vol. 4 (Ed. S. Yamauchi), Kodansha, Tokyo, p.19 (1992).

5) J. Tamaki, Hyomen, 34, 737 (1996).

6) T. Jinkawa, G. Sakai, J. Tamaki, N. Miura, and N. Yamazoe, J. Molecular Catalysis A: Chemical, 155, 193 (2000).

7) J. Tamaki, M. Sakaguchi, K. Fukuzawa, Y. Yamamoto, and M. Matsuoka, Proc. of The 5th East Asian Conf. on Chemical Sensors, p.34 (2001).

8) Y. Nitta, J. Tamaki, Y. Yamamoto, and M. Matsuoka, Proc. of The 5th East Asian Conf. on Chemical Sensors, p. 249 (2001).

9) J. Tamaki, Y. Yagi, K. Fujiwara, K. Matsue, Y. Yamamoto, and M. Matsuoka, Proc. of The 4th East Asian Conf. on Chemical Sensors, p.117 (1999).

10) K. Shono and T. Otsuka, Keisoku Gijutu, 10, 63 (1982).

11) S. Matsushima, T. Maekawa, J. Tamaki, N. Miura, and N. Yamazoe, Chem. Lett., 1989, 845.

12) C. Xu, J. Tamaki, N. Miura, and N. Yamazoe, J. Mater. Sci., 27, 963 (1992). 